\begin{tabular}{|c|c|c|}
\hline (I) & $\begin{array}{c}\text { Journal of Environmental and } \\
\text { Occupational Science }\end{array}$ & 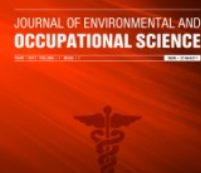 \\
\hline GESDAV & available at www.scopemed.org & (†) \\
\hline
\end{tabular}

Review Article

\title{
Effects of cultural shock on foreign health care professionals: An analysis of key factors
}

\author{
Rakesh Guru ${ }^{1}$, Muhammad A Siddiqui ${ }^{2}$, Zeeshan Ahmed ${ }^{3}$, Adeel Ahmed Khan ${ }^{4}$ \\ ${ }^{I}$ Department of Occupational Therapy, University of Northampton, Northampton, United Kingdom \\ ${ }^{2}$ School of Health Science, Queen Margaret University, Edinburgh, United Kingdom \\ ${ }^{3}$ Department of Community Medicine, Dow University of Health Sciences, Pakistan \\ ${ }^{4}$ Department of Community Health Sciences, Aga Khan University, Pakistan
}

Received: April 15, 2012

Accepted: April 29, 2012

Published: May 3, 2012

DOI : $10.5455 /$ jeos.20120429110947

Corresponding Author:

Zeeshan Ahmed,

Community Medicine Resident

Department of Community Medicine

Dow University of Health Sciences

dr.zeeshan_jmch@yahoo.com

Key words:

Health care professionals, culture, cultural shock, effects of cultural shock.

\begin{abstract}
This review is based upon the foreign health care professionals (FHCP) who go to various developed countries (United Kingdom, United States of America, Australia, Germany and France) from developing countries (India, Pakistan, Africa, Philippines etc) for work to have a better life style, good income, more opportunities, but experienced cultural shock with other types of problem. "Cultural shock" is the mixture of anxiety and feelings of confusion, excitement and insecurity and each person feels it differently. To explore this topic in depth, we divided the topic into separate themes to achieve maximum knowledge that followed by reflection, recommendations and conclusion. FHCP generally feel the unfamiliar environment when they visit to a completely different culture in a foreign country and feel certain problems (familial, professionals, technical etc.) along with cultural shock. Following these findings, we have identified three themes: The first theme will discuss about the cultural shock among FHCP and its impact. The second theme will be a focus on different issues of FHCP about their failure or struggle due to culture shock and third theme which is management challenges in order to establish appropriate culture in organization. For this review, we searched and selected various peer reviewed articles online using search engines and databases including Medline, Scopus, Cinahl and Cochrane and books from the University of Northampton library and peer reviewed journals including International Journal of Intercultural Relations, Human Resources for Health, British Medical Journal and Bulletin of The World Health Organization as well. This review will help to explore different aspects of FHCP such as adjustment with entirely different culture, lack of experience, different lifestyles, face problems being immigrants, and working in a completely different setup with certain rules and regulations.
\end{abstract}

(C) 2012 GESDAV

\section{BACKGROUND:}

The demand for rehabilitation services are increasing regularly in developed countries due to shortages of staff, work pressures, improvement in technology, continuous changing health care needs [1] and lack of competence and managerial worker in their own country [2]. Many studies have identified that in upcoming future there would be more shortages of health care professionals such as physicians, nurses [3], physiotherapists, occupational therapists and speech language pathologists in order to take care of ageing population $[4,5]$.So, the mobility of international health professionals is growing [6] and in this, developing countries are giving their major contribution towards this problem by providing numbers of health professionals to developed countries [7].

Flow of foreign health professionals is not a recent development but it has been in practice since the last decade [8]. This strategy is now becoming a solution in developed countries to deal successfully in health sector by getting benefits from foreign health professionals such as nurses, doctors and other allied 
health professionals [9]. In contrast, World Health Organization (WHO) [10] identified that this flow of health professionals from developing countries can damage health care system of developing countries and this has become the prime topic for debate in international health policy $[9,11]$. According to WHOLIS database [3], countries like UK, USA France, and Canada are mainly dependent upon foreign health care professionals; the majority of them are nurses. In the UK, from 1990, one in ten registrant nurses were from foreign and from 2000-2002 four out of ten nurses were from foreign countries and the source countries were India, Africa, South Africa and Philippines, Zimbabwe [7]. Things would not stop; statistics are showing that USA and UK have to face shortages of nurses in upcoming future and need more recruitment [3]. In favor, Department of Health [12] has considered that International recruitments have given their best contribution for the development of NHS. There are lots of beneficial factors for the recipient countries as through this they easily fill vacant positions which could remain empty for a long time [13].

According to a survey by the UK health departments, the total cost of recruiting a physician or nurse from developing country is less than the overall cost of advertising, training, short-term replacements and prize to appoint experienced nurse from home country which approximately cost $£ 40,000$ [11]. Further, in a study [14] on Canada for health professionals recruitment found that they recruit foreign physicians/ nurses to work in those isolated areas which been far away from basic human necessity such as: away from city, less transportation services, communication facilities and, terrible living conditions. This shows that foreign countries are deliberately deprive migrant health professional from their basic human rights only to save money. In addition, they give fewer wages as compared to their home professionals and also avoid them from added benefits like pensions, social security and worker profits [15].

Therefore, in order to achieve maximum heath care, the health care organizations of developing countries should treat them respectfully to fulfill the gap of skilled health professionals [7]. On the other hand, this fulfillment cause lack of efficient health care professionals in developing countries and being considers the "Brain drain" for them [16]. This not only reduces the chance of health professionals to stay in their countries and serve their people but further weaken the health care system of developing countries [17]. So, developed countries are looking for the solution to slow down the rate of migration of international health professionals [7]. Different people want different things in their life. Some come to developed countries to achieve success and good quality of life whereas some just come to acknowledge the best things and to implement into their home country people for optimal outcome.

There are certain pull factors (good salary, efficient working environment, brighter career opportunities, validity of education, and political stability and push factors (inappropriate wages, poor working conditions, lack of satisfaction and instability at work and less professionals and educational achievement) for foreign health professionals, because different individual has different factors [3]. As per European Commission [18] still the data is not accurate about the need of international health care professionals and very fewer studies had described about the impact and amount of cultural shock and other associated factors in foreign countries.

\section{Theme 1: Cultural shock among foreign health professionals and other aspects:}

\section{Cultural Shock:}

Working in a completely different setup leads to various challenges in which dealing with cultural shock is one of them. Before describing about the cultural shock; first we have to know what the meaning of culture is. Culture is a combination of set patterns of learned behavior that is the typical features of any members of any given society. "Culture refers to the total way of life of particular groups of people. It includes everything that a group of people thinks, says, does and makes -its systems of attitudes and feelings. Culture is learned and transmitted from generation to generation" [19]. Further mentioned in a seminal study [20] that culture is combined setup of mind which creates values, attitudes and behaviors. In that cultural shock occurs in those people who come to different kind of environment and feels disoriented psychologically [21]. It generally occurs due to lack of social dealings, familiar customs, signs and symptom what person used to have is being taken away. In that case person feels like child again and show inability to judge between right and wrong things [22]. An individual usually start his approach with excitement in foreign countries but that is often followed by disappointment which can lead to cultural shock.

Cultural shock is considered as the major barrier for foreign health care professionals to settle in a foreign country $[23,24]$. "Cultural shock" is the emotional and psychological factor that leads to confusion, uncertainty, clashes and certain unidentified reaction that effect person observation and their interaction skill in completely different cultures" [25]. Managing themselves in a different community, with different languages and customs is a serious thing for any foreign worker; in order not to achieve these, person could face depression, frustration and homesickness 
$[23,26]$. Various other factors that also affect cultural shock are lack of proper training, demographic characteristics, organization support and different sort of technical competence.

\section{Stages of Culture Shock:}

There are four stages of cultural shock that is Honeymoon phase (person enjoy in new surrounding and a sense of euphoria) second is Cultural shock phase (person shows his rejection to new things which do not make any sense in new culture), third phase is Adjustment phase (miss his home culture and choose to live in isolation) and last phase is Mastery or Recovery phase (individual develops strategy to deal with new environment and come out from isolation) [27, 28]. The stages of cultural shock can be represented in ' $U$ ' shape curve (Figure I) to define settlement process move from higher to lower level towards more insufficient level and return to good level of satisfaction and coping in new culture [29] but is not necessary to be feel by every migrant person [27].

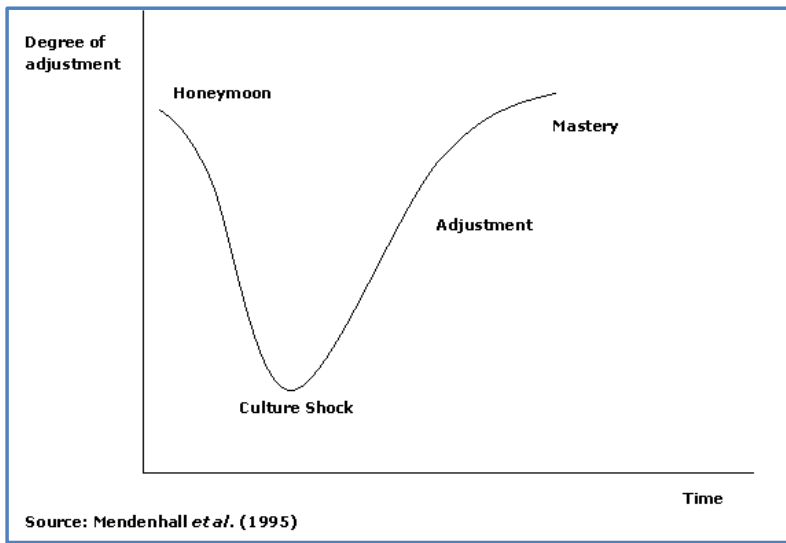

Fig.1: Stages of cultural shock

Cultural shock is not always a bad thing and in some ways can enhance individual learning experience and self-efficacy [30]. It has noticed that now many organizations are fully concentrating on foreign worker management and their personal management [31] but still the failure of foreign health care professionals is very high [32]. Various research and scholars have developed different approaches to rectify the conflict which occur due to cross- culture, but they had little success to achieve this thoroughly due to its complex nature [33]. Several works has been done on this topic but still the information is not sufficient enough which help to live in diverse cultures [34], this definitely demand for learning environment to develop competences with multicultural environment [35]. The World Conference on Higher Education has mentioned the need for exchanging the staff and students in order to gain better understanding about each culture to make a cultural competence health care $[35,36]$.

Further it is stated that differences due to cultural shock could impact on person's motivational factors and orientation at works [20]. Another study mentioned that cultural shock generally occurs due to cultural myopialack of experience and unsolved cultural issues [37]. Dealing with these are not the only problems for foreign health professionals but other such as no value or acceptance of their knowledge or qualifications in another country [38]. This resulted as the cancellation of their license or denying their access to related field. To do more harassments and in order to achieve their standard, the foreign health workers have to prove them by attaining more education programs for better credentials, this could limit the stay of foreign health care professionals for long term specially nurses and doctors [39]. Countries like Australia, USA, New Zealand and Canada are the major countries which do unfair treatment with overseas health professionals and they have to face various issues along with the adjustment of cultural shock [38].

Theme 2: Issues for failure/ struggle of foreign health care professionals as an outsider:

Leaving home country and come to all together different country that mainly depends upon push and pull factors. Migrant's decisions can be inclined by different issues such as social, economical, predeparture and post arrival training, communication, professionals, technical and familial (Figure II). These issues are sometime out of control of policy makers but they are the most important factors [7].

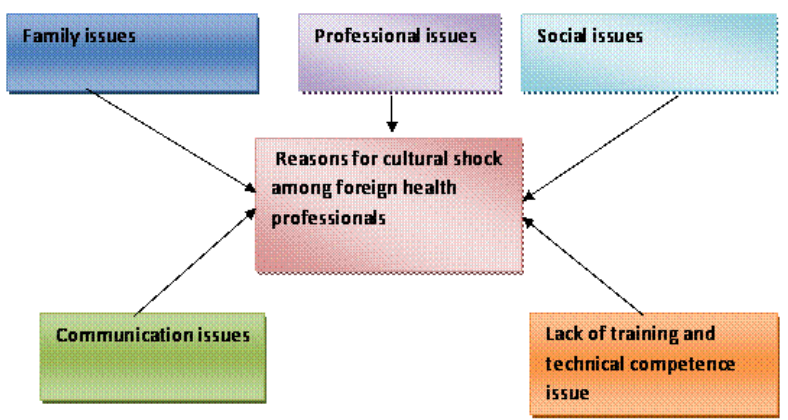

Fig.2: Issues for foreign health care professionals

\section{Social Issues:}

For any developed country skilled migrants health professionals are far more beneficial than the unskilled labor [40]. Most of the foreign health professionals are well settled in UK, USA and Canada (41) but the amount of social isolation what they feel is hard to describe and even harder to judge which is one of the 
main example for cultural shock. Excessive work stress, violence at work, racial and gender discrimination and insufficient pay were also noticed in developed countries' health sectors. [42] Most of the research did not describe about the rejection, marginalization, alienation [43] but discrimination has been observed in many literatures against overseas health professionals [44, 45].

\section{Professionals issue:}

Migrant health professionals are not being paid properly and sometimes recommended lower job distribution, unnoticed their previous job experiences and their competence as a health professionals being questioned [46, 47, 48] Further, in a report [3], most of the nurses and doctors are been supervised by those who had less experiences and newly recruited foreign nurses had to make patients bed in their free time, instead of clinical work. Further, less desirable post fill easily by international health workers in developed countries which would be least interested by their local health professionals [14]. They settled migrant's workers to low quality, rural, underserved and poor locations that further reduces the cost on their living [49]. Not only this, local health professionals treat migrants health professionals inappropriately; that came out in a survey conducted on Canadian professionals and consider them as outsider or foreigner, less proficient and less welcome in the groups and being criticized more for their work and documentation [50]. In the UK, the employers may threaten or put penalties on foreign health professionals if they do not complete their contracts [51]. These factors can effect on their isolation and cause cultural stress.

\section{Familial Issues:}

Family issues are also serious issues for migrants that can leads to cultural shock [52]. It has been consider as the main reason for migrants health professionals failure in adjustment in foreign countries [53]. A research on 500 different organisations was found familial issue is the major factor for the foreign health professionals [25]. Family aspects such as managing children schooling, family health issues and dependent parents are the serious cause of concerns for international health care professionals [53].

\section{Communication:}

Proper communication is always a key to success for foreign health care professionals in order to provide quality care [54]. This will bring better satisfaction to patients and relatives [55]. Culture competence communication is so important that many organizations are now concentrating on cross cultural training of health professionals [56]. In various health sectors, the migrants' health professionals were not capable to understand due to limited English proficiency, and fear of telephonic conversation [50] which sometime resulted as the disclosure of important information regarding patients in front of others [57].

\section{Economic Issues:}

In developing countries most of the health professionals do face certain types of problem like stress at work, low salaries, fight for survival, huge workload, and low motivation, less equipped work place, lack of further training, restricted career opportunities and inadequate supervision [58]. This leads them to move towards private sector or to abroad [59]. Economic issue is a big issue for foreign health care professionals who work in developed countries to maintain their quality of life. Health professionals do get good wages as compared to their home country wages and recipient countries also try to keep them by increasing their wages. So most of the international health workers take good child care, adequate educational opportunities and quality of life work as an incentive for them and are becoming the main reason to stay over.

\section{Lack of Training:}

Training in relevant department (adjustment in different culture) is very necessary to reduce the chances of cultural shock [24]. There is need for proper training and informal visit along with person and his family before entering to other country for job to see the culture and environment [25] to avoid the frustration, dissatisfaction and big cultural shock later after joining the work. Managers from host country are considered them as the waste of time and resources, expensive and ineffective [60] this would be inappropriate for foreign health care professionals. USA spends $\$ 80,000$ on cross cultural training for migrants' worker [24]. In other research cross cultural training is been considered as the positive phase for foreign professionals to avoid the chances of cultural shock and to get indulge quickly in organization culture [61].

\section{Technical issues:}

Developed countries health sector are full with new technologies, which demand an added skill among health professionals. Foreign health professionals do not have much exposure with latest technologies and computer work. Most of the foreign health care professionals struggle initially while dealing with computer work and to take print out. Having these skills are common among home professionals but unusual for international health professionals where they still got the tendency to write report on papers rather than on computer [62]. These skills got less priority in their home country and lead them towards 
stress/ frustration in relation to complete report on time in foreign countries health sector [50].

Theme 3: Management challenges to establish
change for foreign health professionals

\section{Organization Culture:}

Organization culture plays a major role for the success and failure of foreign health care professionals. Culture and environment are the major factors and affects more of the person function. In addition, organization culture generally represent the hidden picture such as the process of thinking, motivation, values, managerial ethics, organization policies and procedures, culture diversity and support, views for employees, leadership behavior rewards and punishments behind big scenarios of that particular organization $[63,64,65]$.

Culture in organization and its policies develop thinking among foreign employees about the levels, restrictions, trust and reliability that become helpful for individual to set himself according to demand [66] . Culture shows relation for the better organizational performance. In the U.K, NHS should put efforts on cross culture to get same focus along with other structural and procedural changes to improve quality and performance [67]. According to Organization for Economic Cooperation and Development [49] countries are now putting their views on cultural renewal process for effective health care improvement [68]. Best cross culture environment in health care sectors defines by its coordinated work, team approach and continuous application of quality improvement practices. The employees suffer less as compared to those who have fake regulations and uncoordinated team work [69]. Evidences to performance and impact of culture are not strong enough that need precaution before putting its implication [70].

Working in different setup with different culture of patients and staffs make situation strange for foreign health care professionals. Many organizations and health sectors show cross culture environment and other defines this to certain section or department [71] .So having rival vary, disagreement, competition and conflicts are quite obvious and in this entire health care sector is to be considered as the most notorious among all organizations [71]. Differences in culture make professionals less flexible to bring any change in them [72]. Many others organizations in health care world have already paid the prize of ignorance. Organization should see the included set of culture points where they have to meet with each other in order to reduce the differences by avoiding internal and external influences [73]. A study had identified company or organisation structures, environment, organisation motive, culture diversity all gives contribution to the organisation to develop appropriate and competent working culture environment. [74]. Despite this, still professionals from different cultures or ethnic background do share specific cultural attribute, example doctors, nurses or managers can be differ culturally but they have to share medical autonomy. It has been clearly indicated in NHS policies documents that managing the culture are the best way to improve health care that need accomplish leader or managers to handle the situation [71].

\section{Leadership/Management}

In health sector, the more the diverse team work together the more difficult to coordinate and such environment demand for a special management/ leadership to direct coordination among diverse group for quality patient care. Complication is developing in every business sector, where need for a quality leader and leadership is necessary to fulfill the purpose [75]. Leadership is a born talent but person can earn through their unique approach and quality handling skills to influence a group, society or organization [76]. Need of leadership become more important when working with diverse culture different ethnic background, in order to understand their feelings [77]. Working with the group of diverse culture brings lots of challenges to leaders and to their management. In order to achieve goals person has to do the things in accurate manners by reducing the risk of chaos, equality among all, health and safety issues and necessary training [78, 79].

In the UK health care system like NHS gives priority to recruit lots of permanent and temporary health care professionals from foreign countries to meet the demand of shortages of staff. In that case, cultural aspect of leadership becomes an important issue in NHS [80]. In addition, working, staffs social and family behavior will change according to perception of the leaders towards the problem. Leaders should create collaborative working environment where health professionals from different disciplines or culture can do work without conflicts [81]. A productive, respectful, and sociable leader would be more successful to understand their staff's problems than the other manager. For this the author of this study has identified few leadership theories to show the actual characteristics of a leader. There are many leadership theories available such as the Great Man theory, Trait theory, Contingency theory, Transactional theory and Transformational theory [82]. The author has chosen Transformational theory to accomplish the demand at work force because this theory gives power, vision, confidence, and truthfulness among leaders to deliver people oriented leadership styles. Not only this, leaders who use transformational theory into their leadership style got the ability to focus for the betterment of organization and building commitment to organizational objectives through empowering 
followers [83].

Transformational theories also known as relationship theory are based on motivation. In this theory the leaders create changes with the help of colleagues [84]. Transformational leaders recognize the motives and desires of others and motivate them to think and act like leaders [85]. Transformational leadership is combined with four components such as Charisma (Unite the work, its value and status of the organization), Inspirational (shows self confidence, ability and dedication), intellectual stimulation (give chance to leader to identify the problem and work according to the need of organization) and Individualized consideration (promote guidance and personal achievements) [86]. Transformational leadership skill is mandatory to change the top level of management in order to perform well [87]. Many researchers have already identified its potential and fruitful outcomes $[88,89]$. In another descriptive study [88], did not find any improvement after using transformational leadership. Transformational leadership is useful in their research [90]. Further, acknowledged that transformational leadership can only be work with those person who wants to do some creative and inspirational to be followed by others [91].

Keeping everyone intact and ability to understand their needs are the major points for success of organisation and leaders [81]. Culture -is the key which motivate employee's behaviours and become vital for the appropriate result of any business. It mainly depends upon leaders/ managers how do they react towards culture based differences in organisation [92]. Leaders have to work on cultural competence which is a set of similar behaviours, attitudes and policies that enclose together in a system to work successfully in a crossculture environment [93]. There are various kinds of cultural competence techniques available for leaders which are helpful to give fruitful information about cross culture and to improve skills of health professionals but very little is known about the effectiveness of these techniques and cost [94].

Having multicultural workforces are not unusual in any international organization but are becoming a necessary part of organizations. In recent years, various literature have mentioned about the cross culture and need of effective cross culture transformational leadership or management $[95,96]$. As the world are deciding to go globally, more diverse labor forces generally come to western countries but international management are not capable enough to handle the workforce of diverse culture. In that, any manager or leader could be considered as the partial and unfaithful from the different culture of persons [97]. Conflicts can be resolve by developing cross cultural leadership/management and by involving transformational leadership style to overcome the problems due to diverse culture and to work collaboratively. Having conflicts and misunderstanding on few topics are common among diverse culture people, which need to solve out by quality leadership and management style [98].

\section{Reflection:}

Going to any foreign country and adjusting in different culture and with different people and diverse working environment are the major factors for foreign health care professionals. This takes time to learn and person gradually develop understanding, because every country has their own system and procedures in their health care and initially getting along with those systems would be hard for any foreign health care workers who do not have such kind of exposure in their home country. We do not have tendency to work in a set procedures, so when someone has to work in set environment and in different language/culture, he struggles and face problems which can be consider as cultural shock. The culture shock can be reduced by good learning and adjustment skills, getting along with others, avoid loneliness and positive approach. Last but not the least; foreign health care professionals have to make efforts in order to fill the gap and to avoid any failure because they are in different country so they have to get along well. Though the roles of management or leaders are very important but they can only provide support, at the end the person has to adjust by himself.

\section{Strategies to implement change to manage cultural shock:}

Managing culture diverse group of people is not an easy task, it requires close encounter with the situation and thorough understanding to eradicate the cause of this disturbance (Charisma). Any organization human resource management is the prime think tank to develop the strategies for reducing cultural shock. [99]. In all the problem, the author has identified that cultural shock generally occur due to inadequate preparation. By having proper training (pre departures and post arrival) someone diminish the cultural shock effect if not able to stop it completely [24]. Not only this, both sides have to learn about the each other culture and the way to adjustment before coming to country for international assignments or hiring people from different culture to avoid any failure in process [100]. Training regarding country and its culture not only give to foreign health care worker but also to their families, language training and advice on child education reduces the amount of cultural shock for foreign health care workers (Inspirational). The leaders approach with good communication and support can also decrease the chances of misunderstanding and increase their 
reputation among diverse culture workforce (Intellectual stimulation) [2].

The leader should focus on emotional and soft skills maturity of foreign health care professionals in order to foster the relationship with other colleagues and to avoid any bias [101]. Foreign health care workers should also have abilities to deal with temporary isolation and alienation and should motivate them to communicate and take part in foreign country cultural activities [102]. The managers or leaders should also attain necessary cross cultural training to identify combined goals, team identity and mutual relationships (Individualized consideration) [103]. Developed countries health care sectors are full with international health care professionals so the leaders or managements are need to define policies and environment according to suitability for all. [104]. Developed countries health sectors should understand the scene for health professionals in their countries and the way they are struggling with it, they should indulge them in their community and should consider them as the part of their community. On the other hand, developing countries should work on different aspects of their health professionals/ students by giving them purposeful exposure in related field and should provide them quality of life in order to retain them in their own country.

\section{CONCLUSION:}

This review on cultural shock for foreign health care professionals from developing countries has given some important points that need to be considered. This investigation has explored the consequences of culture shock on foreign health care professionals about their feeling, reaction and their thinking. This literature has made some general and cultural specific consequences that will help to know about the need of cultural similarities and current differences for them. This review has shown the dearth of literature in this field and maximum literature are showing the overseas nurses and doctors' condition, but very less work have been done on allied health professionals which demand more research to get information in depth. Further, this review has also identify the lack of efficient leaders at management position who can face international challenges and understand the scenarios in order to develop fruitful environment. Cultural shock and inadequate preparation, turned out as the major reason for the failure of international health professionals that need combined approach from developed and developing countries management.

\section{REFERENCES:}

1. Tran D, Hall LM, Davis A, Landry MD, Burnett D,
Berg K, Jaglal S. Identification of recruitment and retention strategies for rehabilitation professionals in Ontario, Canada: results from expert panels.BMC Health Services Research. 2008; 8:249

2. Suttari V, Brewster C. Expatriate Management practices and perceived relevance. Personnel Review. 2000; 30(5):554-577

3. Buchan J, Parkin T, Sochalski J. 2003. International nurse mobility: trends and policy implications. Geneva, World Health Organization WHOLIS database. http://whqlibdoc.who.int/hq/2003/WHO_EIP_OSD 20 03.3.pdf [Accessed on 12/09/2011]

4. Blood GW, Ridenour JS, Thomas EA, Qualls CD, Hammer CS. Predicting job satisfaction among speechlanguage pathologists working in public schools. Language, Speech, and Hearing Services in School. 2002; 33:282-290

5. Von Zweck C. The occupational therapy workforce in Canada. Occupational Therapy Now. 2006; 8:17-20

6. Iredale R. The migration of professionals: theories and typologies. International Migration Quarterly Review. 2001; 39(5):7-27

7. Vujicic M, Zurn P, Diallo K, Adams O, Mario R, Poz $D$. The role of wages in the migration of health care professionals from developing countries. Human Resources for Health. 2004; 2:3-9

8. Adlung R, Carzaniga A. Health services under the general agreement on trade in services. Bulletin of the World Health Organisation. 2001; 79 (4):352-364

9. Chanda R. Trade in health services. Bulletin of the World Health Organization. 2002; 80(2):158-163

10. World Health Organization: International migration and health personnel: a challenge for health systems in developing countries. Agenda item 12.11. Fifty-seventh World Health Assembly: Health Systems Including Primary Care. 2002; 22 Geneva

11. Buchan J. Here to Stay? International Nurses in the UK. Queen Margrets University College, Edinburgh. 2002.

12. Department of Health: Code of practice for NHS employers involved in the international recruitment of healthcare professionals. London: Department of Health. 2001

13. Briggs, J: The International Migration of Health Staff, International Health Division School of Tropical Medicine. Liverpool. 2000.

14. Bundred PE, Levitt CA. 'Medical Migration: Who are the real losers?' Lancet. 2000; 356: 245-6

15. Martineau T, Decker K, Bundred P. 2002. Briefing note on international migration of health professionals: Levelling the playing field for developing health systems, International Health Division School of Tropical Medicine, Liverpool. www.liv.ac.uk/lstm/hsrhome.html [Accessed at 05/09/2011] 
16. Kangasniemi L, Winters A, Commander S. Is the medical brain drain beneficial? Evidence from overseas doctors in the UK. Social Science \& Medicine.2007; 65: 915-923

17. Astor A, Akhtar T, Matallana MA, Muthuswamy M, Olowu FA, Tallo V. et al. Physician migration: views from professionals in Colombia, Nigeria, India, Pakistan and the Philippines. Social Science \& Medicine. 2005; 61, 2492-2500

18. European Commission: Follow-up to the high level reflection process on patient mobility and healthcare developments in the European Union. COM 2004/301, 20 April. Brussels, Commission of the European Communities. 2004

19. Kohls LR. Survival Kit for Overseas Living, Maine: Intercultural Press, Inc. 1996.

20. Milikic BB, Janicijevic N. Cultural divergence and performance evolution system: A comparative study of three Serbian companies. Economic Annals. 2009; 54(180):40-55

21. Piet-Pelon NJ, Hornby B. Women guide to overseas living. 2ed edition. Intercultural Press. Yarmouth, Me. 1992

22. Walton S. Stress management training for overseas effectiveness. International Journal of Intercultural Relations.1990; 14: 507-27

23. Black JS. Personal dimensions and work role transitions. Management International Review. 1990. 30: $119-134$

24. Harrison JK. Developing successful expatriate managers. Human Resource Planning. 1994; 17:17-33

25. Solomon CM. Success abroad depends on more than job skills. Personal Journal.1994; 4:51-59

26. Winkelman M. "Cultural Shock and Adaptation." Journal of Counseling \& Development. 1994; 73 (2):121-126

27. Wild R, Griggs K, Downing T. "A framework for elearning as a tool for knowledge management". Industrial Management \& Data Systems. 2000; 102(7):371-80

28. Foley M. What is cultural shock? http://workabroadtravel.suite101.com/article.cfm/whatis-culture-shock. [Accessed at 05/09/2011]

29. Pedersen P. The Five Stages of Culture Shock: Critical Incidents around the World. Westport, CT. pp. 12.Greenwood Press, 1995

30. Milstein T. Transformation abroad: Sojourning and the perceived enhancement of self efficacy. International Journal of Intercultural Relations.2005; 29(2):217-238

31. Anderson BA. Expatriate Selection: Good Management or Good Luck? International Journal of Human Resource Management. 2005; 16 (4):567-583

32. Black JS, Gregersen HB. The right way to manage expatriates. Harvard Business Review. 1999; 77: 52-63
33. Denison DR, Haaland S, Goelzer P. Corporate Culture and Organizational Effectiveness: Is Asia Different From the Rest of the World? Organizational Dynamics. 2004; 33(1):98-109

34. McCabe JA. An assignment for building an awareness of the intersection of health literacy and cultural competence skills. Journal of Medical Library Assoc.2006; 94 (4):458-461

35. Callen BL, Lee JL. Ready for the world: Preparing nursing students for tomorrow. Journal of Professional Nursing. 2009; 25(5): 292-298

36. World Conference on Higher Education. The New Dynamics of Higher Education and Research for Societal Change and Development, COMMUNIQUE. 2009

37. Osland J, Bird A. Beyond Sophisticated Stereotyping: Cultural Sense making in Context. Academy of Management Executive. 2000; 14(1):65-77

38. Iredale R. Luring Overseas Trained Doctors to Australia: Issues of Training, Regulating and Trading'. International Migration. 2009; 47 (4):31-65

39. Redfoot L, Houser AN. "We Shall Travel On": Quality of Care, Economic Development, and the International Migration of Long-Term Care Workers, AARP Public Policy Institute, Washington DC, 2005

40. Wickramasekara, P. Asian labor migration: Issues and challenges in an era of globalization, International Migration Papers 57. Geneva. 2002

41. Khadria B. Skilled labour migration from developing countries: Study of India, International Migration Papers No. 49. International Labor Office, Geneva. 2002

42. Bach S. International migration of health workers: labour and social issues. Geneva: Sectorial Activities Programme, International Labour Office; (WP 209).2003

43. Canales MK. Othering: toward an understanding of difference. Advances in Nursing Science.2000; 22 (4):16-31

44. Kline DS. Push and pull factors in international nurse migration. Journal of Nursing Scholarship.2003; 35 (2):107-111

45. Stalker P. Migration trends and migration policy in Europe. InternationalMigration.2002; 40 (5):151-179

46. De Beiji R. Documenting discrimination against migrant workers in the labour market. Geneva, ILO. 2000

47. De Jong G, Madamba A. "A double disadvantage? Minority group, immigrant status and underemployment in the United States", Social Science Quarterly, 2001; 82:117-130

48. Royal College of Nursing: 2003. "We Need Respect", Experiences of Internationally Recruited Nurses in the UK 
http://www.ren.org.uk/downloads/international/irn rep ort_we_need_respect.pdf. [Accessed on 16/09/2011]

49. Organisation for Economic Co-operation and Development: International Migration of Physicians and Nurses: Causes, Consequences, and Health Policy Implications, 2002 OECD Paris

50. Magnusdottir H. Overcoming strangeness and communication barriers: a phenomenological study of becoming a foreign nurse. International Nursing Review. 2005; 52:263-269

51. Johnson, F., and Oldham, M: "International recruitment: Learning the hard way", in Health Services Journal. 2001; 111(5759):30

52. Black JS, Gregersen HB. Antecedents to cross-cultural adjustment for expatriates in Pacific Rim assignments. Human Relations. 1991; 44(5):497-515

53. Takeuchi et al. An examination of crossover and spillover effects of spousal and expatriate cross-cultural adjustment on expatriate outcomes. Journal of Applied Psychology. 2002; 87: 655-666

54. Taylor S, Lurie N. The role of culturally competent communication in reducing ethnic and racial healthcare disparities. Am J Managed Care. 2004; 10:1-4

55. Weech-Maldonado R, Morales LS, Spritzer K, Elliot M, Hays RD. Racial and ethnic differences in parents' assessments of pediatric care in Medicaid managed care. Health Serv Res. 2001; 36(3):575-595

56. Council on Graduate Medical Education: Physician Education for a Changing Health Care Environment. 13th report. 1999. Health Resources and Services Administration, US Department of Health and Human Services. http://www.cogme.gov/13.pdf. [Accessed on 10/09/2010]

57. Elderkin-Thompson V, Silver RC, Waitzkin H. When nurses double as interpreters: a study of Spanishspeaking patients in a US primary care setting. SocSciMed, 2001; 52(9):1343-1358

58. United States Agency for International Development: The Health Sector Human Resources Crisis in Africa: An issues paper Washington, DC: USAID Bureau for Africa, Office of Sustainable Development. 2001

59. Mutizwa-Mangiza D. The impact of health sector reform on public sector health worker motivation in Zimbabwe. Major Applied Research Working Paper. Partnerships for Health Reform.Bethesda: Abt Associates. 1998

60. Black JS, Gregersen HB, Mendanhall ME, Stroh L. Globalizing People through International Assignments (1999). 1st ed. Reading, MA: Addison-Wedley Publishing.

61. Deshpande SP, Viswesvaran C. Is cross-cultural training of expatriate managers effective: A Metaanalysis. International Journal of Intercultural Relations. 1992; 16: 295-310

62. Shamash J. Finders keepers. For description of local initiatives on induction of international Nurses. Nursing Times.2002; 98 (21

63. Alvesson M, Sveningsson S. Changing Organizational Culture, Cultural change work in progress; 1998. Newyork. Routledge.

64. Brass DJ, Butterfield KD, Skaggs BC. Relationships and Unethical Behavior: A Social Network Perspective. Academy of Management Review. 1998; 23(1):14-31

65. Chinn PL, Kramer MK. Theory and Nursing: Integrated Knowledge Development. 5th ed., St. Louis. 1999. Mosby.

66. Aroskar MA. 1998. Administrative Ethics: Perspectives on Patients and Community-Based Care.Journal of Issues in Nursing. http://www.nursingworld.org/ojin [Accessed on 14/09/2011].

67. Department of Health and Human Services. 2000. Report to Congress: The pharmacist workforce: A study of the supply and demand for pharmacists http://newsroom.hrsa.gov/releases/2000Releases/pharm acistshortage.htm [Accessed on 16/09/2011]

68. Smith P. Measuring up: Improving health system performance in OECD countries. OECD: Paris. 2002

69. Ferlie E, Shortell S. Improving the quality of health care in the UK and the USA: a framework for change. Millbank Q. 2001; 79: 281-316

70. Scott T, Mannon R, Davies HTO, Marshall MN. Implementing culture change in health care: Theory and practice. International Journal for Quality in Health Care. 2003; 15 (2): 111-118

71. Davies HTO, Nutley SM, Mannion R. Organisational culture and quality of health care. Qual Health Care. 2000. 9:111-119

72. Harrison J, Nutley SM. Professions and management in the public sector: the experience of local government and the NHS in Britain. In: Leopold J, Glover I, Hughes M, (eds), Beyond Reason: The National Health Service and the Limits of Management. Aldershot: Avebury. 1996

73. Schneider Y. Advocacy: A Background Paper for the 1st National Summit of Mental Health Consumers and Survivors. Portland, Oregon.1999

74. Hagberg R, Heifetz J. Corporate culture/organizational culture: Understanding and assessment, telling the CEO his/her baby is ugly. http://www.hegnet.com/html/articles/understanding Culture.html. [Accessed on 15/08/11].

75. Northouse PG. Leadership Theory and Practice, 4th ed. London; Sage publications, 2007, p. 3

76. Mariotti J. On management: The role of a leader. http://www.industryweek.com/columns/asp/columns.as p?ColumnId=409. [Accessed on 15/08/11].

77. Hewison A, Griffiths M. Leadership development in health care: A word of caution. Journal of Health Organisation and Management. 2004. 18(6):464-473 
78. Kotter JP. What leaders really do. Harvard Business Review. 2001; 79(11):85-91(2001).

79. McConnell CR. The effective health care supervisor.5th edition. Gaithersburg,MD: Aspen Publishers. 2002.

80. Littrell RF. Desirable leadership behaviours of multicultural managers in China. Journal of Management Development. 2002; 21:5-73

81. Goleman, D: What Makes a Leader? Harvard Business Review. 93-102(1998).

82. Wagner K V. About.com: Psychology. Leadership Theories.

http://psychology.about.com/od/leadership/p/leadtheori es.htm [Accessed on 15/05/2011]

83. Stone AG, Russell RF, Patterson K. Transformational versus servant leadership: A difference in leader focus. Leadership \& Organization Development Journal. 2004; 25(4):349-361

84. Lowe KB, Kroeck KG, Sivasubramaniam N. Effectiveness correlates of transformational and transactional leadership: A meta-analytic review of the MLQ literature. Leadership Quarterly. 1996; 7:385-425

85. Bass B M. Transformational leadership: Industrial, military, and educational impact. Mahwah, NJ: Erlbaum. 1998.

86. Madhu B, Krishnan VR. Impact of transformational leadership and karma-yoga on organizational citizenship behaviour, Prestige Journal of management and research. 2005; 9(1):120

87. Jackson D. The school improvement journey: perspectives on leadership. School Leadership \& Management.2000; 20(1):61-78

88. Yukl G. An Evaluative Essay on Current Conceptions of Effective Leadership. European journal of work and organizational psychology.1999; 8(1):33-48

89. Podsakoff PM, MacKenzie SB, Morrman RH, Fetter R. Transformationalm leader behaviours and their effects on follower's trust in leader, satisfaction, and organizational citizenship behaviors. Leadership Quarterly. 1990; 1:107-142

90. Ross SM, Offerman L R. Transformational Leaders: Measurement of personality attributes and work group performance. Personality and social Psychology Bulletin. 1997; 23(10):1078-1086

91. Fry L. Toward a theory of spiritual leadership. The Leadership Quarterly.2003; 14: 693-727

92. Saya F, Gbarayor M. The Case for Cultural Competence in Health Professions Education.
American Journal of Pharmaceutical Education. 2006; $70(6): 1-6$

93. National Centre for Cultural Competence: Conceptual Frameworks/Models, Guiding Values and Principles, Washington DC, Georgetown University Child Development Centre.2006

94. Beach MC, Price EG, Gary TL et al. Cultural competence: a systematic review of health care provider educational interventions. Med Care. 2005; 43:356-73

95. Brower HH, Schoorman FD, Tan HH. A model of relational leadership: the integration of trust and leadermember exchange. Leadership Quarterly. 2000; 11: $227-250$

96. Uhl-Bien M, Maslyn JM. Reciprocity in managersubordinate relationships: components, configurations, \& outcomes. Journal of Management. 2003; 29 (4):511- 532

97. Adler NJ. International Dimensions of Organizational Behavior. South-Western/Thomson Learning, Cincinnati, OH. 2002.

98. Chen YF, Tjosvold D. Cross-cultural leadership: Goal interdependence and leader-member relations in foreign ventures in China. Journal of International Management.2005; 11: 417-439

99. Deresky H. International Management: managing across borders and cultures. 4th ed. New Jersey: Pearson Education Inc. 2003

100. Chew J. 2004. Managing MNC Expatriates through Crises: A challenge for International Human Resource Management. Research and Practice in Human $\begin{array}{llll}\text { Resource } & \text { Management. } 12 & \text { (2): } 1-30 .\end{array}$ http://rphrm.curtin.edu.au/2004/issue2/expats.html [Accessed on 05/08/10].

101. Demers J. Crossing the Cultural Divides. CMA Management. 2002; 76 (6):27-30

102. Sullivan P. Canada a prime destination as MDs flee South Africa. Canadian Medical Association Journal. 1999; 160(11):1615-1616

103. Pearce RJ. Towards understanding joint venture performance and survival: a bargaining and influence approach to transaction cost theory. Academy of Management Review. 1997; 22:203-235

104. Tung RL. Managing cross cultural and international diversity. Human Resource Management. 1993; 32 (4):461

This article is an open access article licensed under the terms of the Creative Commons Attribution Non-Commercial License (http://creativecommons.org/licenses/by-sa/3.0/) which permits unrestricted, non-commercial use, distribution and reproduction in any medium, provided the work is properly cited. 